\title{
Erratum to: Association of $I L-1 R a$ and $I L-4$ Gene VNTRs with Susceptibility to Prostate Cancer in Turkish Population
}

\author{
G. Bingöl ${ }^{a, *}$, F. Polat ${ }^{b}$, and S. B. Diler ${ }^{c}$ \\ ${ }^{a}$ Department of Biomedical Engineering, Faculty of Engineering and Natural Sciences, \\ Ankara Yuldırtm Beyazt University, Ankara, Turkey \\ ${ }^{b}$ Department of Mathematics and Science Education, Faculty of Education, Kocaeli University, Kocaeli, Turkey \\ ${ }^{c}$ Department of Biotechnology, Faculty of Science and Literature, Nigde Omer Halisdemir University, Nigde, Turkey \\ *e-mail: gbingol@gmail.com \\ Submitted November 11, 2020; accepted for publication November 11, 2020
}

DOI: $10.3103 / \mathrm{S} 0095452721010060$

Section References, numbers [16] and [17] should read [16].

The total number of References should read 32.

The original article can be found online at https://doi.org/10.3103/S0095452720050138 